\title{
Effect of genetic merit for energy balance on luteal activity and subsequent reproductive performance in primiparous Holstein-Friesian cows
}

\author{
R. von Leesen, ${ }^{*}$ J. Tetens, ${ }^{*}$ E. Stamer,† W. Junge, ${ }^{*}$ G. Thaller, ${ }^{*}$ and N. Krattenmacher ${ }^{\star 1}$ \\ ${ }^{*}$ Institute of Animal Breeding and Husbandry, Christian-Albrechts-University, D-24118 Kiel, Germany \\ †TiDaTier und Daten GmbH, D-24259 Westensee/Brux, Germany
}

\begin{abstract}
Postpartum energy status is critically important to fertility. However, studies dealing with the relationship between both traits are rare and most refer only to the phenotypic level. In this study, random regression models were used to generate cow-specific lactation curves for daily breeding values (BV) of energy balance (EB) to assess the effect of genetic merit for energy status on different traits derived from progesterone profiles and on subsequent reproductive performance of high-producing dairy cows. Individual feed intake, milk yield, and live weight were recorded for lactation d 11 to 180, and EB was estimated on a daily basis. The results provided the basis for the estimation of BV for 824 primiparous Holstein-Friesian cows. For a subset of these cows $(\mathrm{n}=334)$, progesterone profiles for the resumption of ovarian activity were available. Four different traits describing the genetic merit for EB were defined to evaluate their relationship with fertility. Two EB traits referred to the period in which the average daily EB across all cows was negative (d 11 to 55 postpartum), and 2 parameters were designed considering only daily BV for d 11 to 180 in lactation that were negative. We found that cows with a high genetic merit for EB had a significantly earlier resumption of ovarian activity postpartum. Thus, an EB (indicator) trait should be included in future breeding programs to reduce the currently prolonged anovulatory intervals after parturition.
\end{abstract}

Key words: dairy cow, energy balance, luteal activity, reproductive performance

\section{INTRODUCTION}

Milk production per cow has been considerably improved over the last decades (Lucy, 2001), but the success in breeding for milk yield has been accompanied by negative side-effects, especially in terms of an

Received June 26, 2013.

Accepted November 5, 2013.

${ }^{1}$ Corresponding author: nkrattennmacher@tierzucht.uni-kiel.de aggravated negative energy balance (EB) in early lactation. Cows require sufficient energy intake to support all physiological functions; that is, to produce milk and grow while maintaining fitness and reproducing (Banos et al., 2006). However, DMI is insufficient to cover the demand in early lactation and, according to Collard et al. (2000), selection for milk traits has resulted in a partial shift of available energy toward milk production at the cost of other biological pathways. Additional energy for milk production is made available by mobilization of body fat and skeletal muscle (Butler and Smith, 1989; Bell, 1995). Bauman and Currie (1980) demonstrated that the average EB of high-yielding dairy cows was negative during the first 100 DIM. Beever et al. (1998), studying cows fed a high-quality diet at an intake level $>28 \mathrm{~kg}$ of $\mathrm{DM} / \mathrm{d}$, reported that the period of negative EB can even persist for 20 wk after parturition. During this critical period ( $\sim 80 \mathrm{~d}$ after calving), the majority of farmers aim to get their cows pregnant again to achieve a calving interval of approximately 1 yr. This situation has given cause for concern but studies dealing with EB and fertility traits are rare, mainly because recording of individual feed intake is costly and difficult to apply in practice (Hüttmann et al., 2009). Available data sets are generally small. Nevertheless, several studies have reported negative effects of an energy deficit or losses of body energy on the reproductive performance of dairy cows. Reist et al. (2003) found that cows exhibiting a severe or prolonged negative EB remained open for longer. This was in line with the results of Patton et al. (2007), who stated that cows not experiencing a pronounced energy deficit have an increased likelihood of conception at first service. A few studies also investigated the genetic association of directly measured body energy and reproductive performance: Veerkamp et al. (2000) reported negative genetic correlations between measures of $\mathrm{EB}$ and the interval from calving to first luteal activity (commencement of luteal activity; CLA). This is in line with Banos and Coffey (2010), who reported negative genetic correlations between the interval from calving to the first observed estrus and daily EB, energy content, cumulative effective energy, and BCS. For EB, this was true only for the first 105 
DIM, whereas for the other traits, all daily estimates (DIM 4 to 311) were significant. Significant correlations with CLA were found only for the first $107 \mathrm{~d}$ of energy content and the first $222 \mathrm{~d}$ of BCS. These results substantiate the need to accomplish further investigations on the genetic association between traits for body energy and reproductive performance.

The objectives of this study were (1) to define adequate parameters characterizing cow-specific lactation curves for daily breeding values (BV) of EB, and (2) to estimate the effect of these parameters on the resumption of first luteal activity postpartum as well as on subsequent reproductive performance. To the best of our knowledge, no comparable research has been done on this issue to date.

\section{MATERIALS AND METHODS}

\section{Energy Balance Raw Data and Estimation of Daily Breeding Values}

Data were collected from primiparous HolsteinFriesian cows. Data recording was done between March 2006 and December 2012 on the dairy research farm Karkendamm (Bimöhlen, Germany). This farm runs a bull dam performance test, and all Karkendamm bull dam candidates had to complete a test period under commercial conditions in a freestall barn until DIM 180. Nonqualified primiparous cows left the herd afterward. Therefore, only records between 11 (start of feed intake recording) and 180 DIM were used in the present investigation. Animals were milked twice a day and milk yield was recorded at every milking. Milk composition was analyzed weekly based on samples collected from 2 consecutive milkings. Milk was corrected for energy following the formula of Kirchgeßner (1997):

$$
\begin{gathered}
\operatorname{ECM}(\mathrm{kg})=(0.39 \times \text { fat } \%+0.24 \times \text { protein } \% \\
+0.17 \times \text { lactose } \%) \times \text { milk yield }(\mathrm{kg}) / 3.17
\end{gathered}
$$

For this purpose, milk composition per day was obtained by weighting the respective or previous analysis values per day with the respective milk yield. Cows were weighed after every milking and the daily value was derived by averaging morning and evening BW. Animals were fed a TMR ad libitum, and daily intake was recorded for each animal via single feeding troughs. As cows were generally housed separately during the first 10 DIM, no feed intake data were available for this period. The average $\mathrm{NE}_{\mathrm{L}}$ of the TMR was $7.1 \mathrm{MJ} / \mathrm{kg}$ of DM. Fixed amounts of concentrates were dispensed via concentrate feeders. Energy balance was calculated as described by Buttchereit et al. (2010). Animals were discarded from the analyses if the number of EB estimates per cow across the entire period was fewer than 4. This resulted in 824 primiparous cows and an average of $83 \mathrm{~EB}$ estimates per cow.

A pedigree file was created by tracing the pedigree of cows with data 3 generations back. The resulting file consisted of 5,683 animals. Energy balance BV (EBBV) were estimated via ASReml 3.0 (Gilmour et al., 2009) using a random regression animal model. Test-day, age at first calving, and stage of lactation were considered as fixed effects. Age at first calving was divided into 5 classes (21 to 25, 26, 27, 28, and 29 to $38 \mathrm{mo}$ ). The general lactation curve was modeled by the function according to Ali and Schaeffer (1987), and random regression coefficients for permanent and additive genetic effects were modeled applying Legendre polynomials of 2 degrees:

$$
\begin{aligned}
y_{i j k l m}= & T D_{i}+A F C_{j}+\sum_{n=1}^{4} b_{n} x_{i j k l m n}(d)+\sum_{n=0}^{2} p_{k n} x_{i j k l m n}(d) \\
& +\sum_{n=0}^{2} a_{l n} x_{i j k l m n}(d)+e_{i j k l m},
\end{aligned}
$$

where $y_{i j k l m}$ is the $m$ th observation of $\mathrm{EB}, T D_{i}$ represents the fixed effect of the test-day $i(i=1$ to 1,714),

\begin{tabular}{|c|c|c|c|c|c|}
\hline Trait & $\begin{array}{c}\text { No. of } \\
\text { observations }\end{array}$ & Mean & SD & Minimum & Maximum \\
\hline Age at first calving (mo) & 824 & 27.36 & 2.33 & 21.00 & 38.00 \\
\hline ECM $(\mathrm{kg} / \mathrm{d})$ & 165,805 & 32.72 & 4.69 & 2.50 & 53.64 \\
\hline Fat $(\%)$ & 24,138 & 3.64 & 0.59 & 1.22 & 8.68 \\
\hline Protein (\%) & 24,138 & 3.24 & 0.24 & 1.96 & 6.01 \\
\hline Lactose (\%) & 24,237 & 4.88 & 0.15 & 3.17 & 5.38 \\
\hline $\mathrm{EB}\left(\mathrm{MJ}\right.$ of $\left.\mathrm{NE}_{\mathrm{L}} / \mathrm{d}\right)$ & 68,436 & 5.16 & 35.86 & -141.80 & 185.59 \\
\hline DMI $(\mathrm{kg} / \mathrm{d})$ & 93,797 & 20.17 & 4.83 & 1.99 & 45.45 \\
\hline $\mathrm{BCS}$ & 5,662 & 2.95 & 0.33 & 1.50 & 3.90 \\
\hline BW (kg) & 130,452 & 600.03 & 54.48 & 404.00 & 847.00 \\
\hline
\end{tabular}
and $A F C_{j}$ is the fixed effect of age at first calving $(j=$

Table 1. Descriptive statistics for ECM, fat content, protein content, lactose content, energy balance (EB), DMI, BCS, and BW ( $\mathrm{n}=824$ primiparous dairy cows, DIM 11 to 180) 
Table 2. Overview of group assignment according to the difference between energy balance breeding values (BV) for DIM 11 and $55(\mathrm{n}=334$ primiparous cows)

\begin{tabular}{|c|c|c|c|}
\hline \multicolumn{2}{|c|}{ Difference between BV for DIM 11 and 55} & \multirow{2}{*}{$\frac{\text { Class limit }^{1}}{\mathrm{i} \geq 7.16}$} & \multirow{2}{*}{$\frac{\text { Frequency, \% (no.) }}{29.04(97)}$} \\
\hline $\begin{array}{l}\text { Positive difference } \\
\text { (downward sloping BV curve) }\end{array}$ & Greater than mean $+1 / 2 \mathrm{SD}$ & & \\
\hline $\begin{array}{l}\text { Low to moderate difference } \\
\text { (flat BV curve) }\end{array}$ & Mean $\pm 1 / 2 \mathrm{SD}$ & $-2.96<\mathrm{i}<7.16$ & $55.99(187)$ \\
\hline $\begin{array}{l}\text { Negative difference } \\
\text { (rising BV curve) }\end{array}$ & Less than mean $-1 / 2 \mathrm{SD}$ & $\mathrm{i} \leq-2.96$ & $14.97(50)$ \\
\hline
\end{tabular}

${ }^{1}$ Where class limit $\mathrm{i}$ is the difference between BV for DIM 11 and 55.

1 to 5$), b_{n}$ are the fixed regression coefficients on lactation day $d$ with $x_{i j k l m 1}(d)=d / 190, x_{i j k l m 2}(d)=(d / 190)^{2}$, $x_{i j k l m 3}(d)=\ln (190 / d)$, and $x_{i j k l m 4}(d)=[\ln (190 / d)]^{2}$, $p_{k}$ represents the random regression coefficients for the permanent environmental effect of animal $k$, and $a_{l}$ are the random regression coefficients for the additive genetic effect of the lth animal with $x_{i j k l m 0}(d)=1$, $x_{i j k l m 1}(d)=-1+2\left(d-11 / d_{\max }-11\right)$ and $x_{i j k l m 2}(d)=$ $0.5\left\{3\left[-1+2\left(d-11 / d_{\max }-11\right)\right]^{2}-1\right\}(k=1$ to $824, l$ $=1$ to 5,683$)$, and $e_{i j k l m}$ is the random error term.

Table 1 provides an overview of means, standard deviations, minima, and maxima of age at first calving, ECM, fat, protein, and lactose contents, EB, DMI, $\mathrm{BCS}$, and BW.

\section{Characterization of Cow-Specific Lactation Curves for Daily EBBV}

Cow-specific lactation curves for EBBV showed considerable variation. Either early lactation BV were initially positive and decreased approximately linearly over time to become negative or BV were negative in the beginning and increased approximately linearly over time to become positive. Over the whole period, curves for daily BV were concave, convex or showed no such remarkable pattern. These characteristics of the daily EB BV curves were used to define 4 different parameters describing the genetic merit for energy status. According to these parameters, cows were assigned to different groups. A detailed explanation is given below.

\section{Difference Between BV for DIM 11 and 55}

This parameter characterizes the change of genetic merit for EB from DIM 11 to 55. Using this parameter,
3 groups were defined. Class limits were obtained by adding $1 / 2$ standard deviation (SD) to the mean and subtracting $1 / 2$ SD from the mean, respectively (Table 2 ). For example, the difference between BV for DIM 11 and DIM 55 was positive if cows had a positive BV at 11 DIM and a negative BV at 55 DIM. Cows with a concave or convex cow-specific lactation curve for daily EBBV were correctly classified, because the reverse occurred in a later stage of lactation (after 55 DIM).

\section{Average BV from DIM 11 to 55}

This parameter also refers to the period in which the average daily EB across all cows was negative (DIM 11 to 55). The average level of genetic merit for EB was calculated for this period and 3 groups were formed using the same procedure as described above (Table 3 ).

\section{Sum and Number of Negative BV from DIM 11 to 180}

The sum of negative EBBV from DIM 11 to 180 was calculated to describe the genetic disposition for the magnitude of the energy deficit postpartum. In total, 234 cows had negative EBBV throughout the whole observation period. Three groups were defined using the same procedure as described before (Table 4).

The number of negative EBBV from DIM 11 to 180 was calculated to describe the genetic predisposition for a prolonged negative EB. As described before, 3 subgroups were defined (Table 5).

\section{Progesterone Measurements}

For a subset of cows with EBBV, progesterone records were available from April 2007 to December

Table 3. Overview of group assignment according to the average energy balance breeding value (BV) across DIM 11 to 55 ( $\mathrm{n}=334$ primiparous cows)

\begin{tabular}{|c|c|c|c|}
\hline \multicolumn{2}{|c|}{ Average BV for DIM 11 to 55} & Class limit ${ }^{1}$ & Frequency, \% (no.) \\
\hline High mean BV & Greater than BV mean $+1 / 2 \mathrm{SD}$ & $\mathrm{i} \geq 10.44$ & $31.44(105)$ \\
\hline Medium mean BV & Mean BV $\pm 1 / 2 \mathrm{SD}$ & $-7.04<\mathrm{i}<10.44$ & $44.61(149)$ \\
\hline Low mean BV & Less than mean $\mathrm{BV}-1 / 2 \mathrm{SD}$ & $\mathrm{i} \leq-7.04$ & $23.95(80)$ \\
\hline
\end{tabular}

${ }^{1}$ Where class limit $\mathrm{i}$ is the average BV for DIM 11 to 55 
Table 4. Overview of group assignment according to the sum of negative energy balance breeding values (BV) from DIM 11 to 180 ( $\mathrm{n}=234$ primiparous cows)

\begin{tabular}{lccc}
\hline Sum of negative BV across the entire period (DIM 11 to 180) & Class limit & Frequency, \% (no.) \\
\hline Low negative & Greater than mean sum of negative BV $+1 / 2 \mathrm{SD}$ & $\mathrm{i} \geq-617.43$ & $43.59(102)$ \\
Moderate negative & Mean sum of negative BV $\pm 1 / 2 \mathrm{SD}$ & $\mathrm{i} \leq-617.43>\mathrm{i}>-2,170.64$ & $33.33(78)$ \\
High negative & Less than mean sum of negative BV $-1 / 2 \mathrm{SD}$ & $23.08(54)$ & \\
\hline
\end{tabular}

${ }^{1}$ Where class limit $\mathrm{i}$ is the sum of negative BV across the entire period (DIM 11 to 180).

2008 and from February 2010 to December 2011. Milk samples (about $5 \mathrm{~mL}$ of foremilk) were taken twice a week on Monday morning and Thursday afternoon. Sampling period was about $6 \mathrm{~d}$ after parturition to 30 $\mathrm{d}$ after a positive ultrasonographic pregnancy diagnosis. Milk samples were stored with no preservatives at $-18^{\circ} \mathrm{C}$ until enzyme immunoassays for progesterone were conducted. Progesterone quantification was done from aliquots of $20 \mu \mathrm{L}$ of skim milk applying the ELISA procedure, which uses a monoclonal progesterone antibody bound to the surface of a 96-well microplate. Horseradish peroxidase was used as conjugate and tetramethylbenzidine as chromogen. The reaction was stopped by addition of $50 \mu \mathrm{L}$ of $2 \mathrm{M} \mathrm{H}_{2} \mathrm{SO}_{4}$ /well. Optical density was measured and plotted against the mass of conjugate with a wavelength of $450 \mathrm{~nm}$ using an SLT Spectra photometer (Tecan, Männedorf, Switzerland). To determine the measuring accuracy, the accuracy in duplicates approach by Doerffel (Renner, 1970) was applied. The accuracy was defined as follows:

$$
\text { Accuracy }=\sqrt{\frac{\sum\left(x_{1}-x_{2}\right)^{2}}{2 \times n}},
$$

where $x_{1}$ and $x_{2}$ was one pair of duplicates and $n$ was the number of pairs. For this purpose, milk samples from 2 cows in heat (low progesterone concentration) and 1 pregnant cow (high progesterone concentration) were used. The degree of accuracy for the low concentration was $\pm 0.034 \%$ and $\pm 0.027 \%$, for the 2 cows, respectively, and was $\pm 0.012 \%$ for the high concentration. Thus, there was a discrepancy of $\pm 0.034 \%$ between $x_{1}$ and $x_{2}$ for low concentrations. Cows were included in this study if the first progesterone measurement was before 10 DIM. Cows with fewer than 12 subsequent observations in $42 \mathrm{~d}$ were excluded. In addition, cows were excluded if there were gaps in the time series greater than $14 \mathrm{~d}$. Finally, 334 first-lactation dairy cows remained for this study.

\section{Characterization of Luteal Activity Based on Progesterone Profiles}

Data preparation of progesterone measures was done in $\mathrm{R}$ ( $\mathrm{R}$ Development Core Team, 2012). The R package "stinepack" with the included subfunction "scaledstineman" (Johannesson et al., 2009) was used to interpolate the time series. The black dashed line in Figure 1 illustrates the interpolation. First luteal activity was determined by the first postpartum progesterone value above the threshold value of $0.8 \mathrm{ng}$ of progesterone/ $\mathrm{mL}$ of skim milk, preceded by low progesterone. The threshold $(0.8 \mathrm{ng} / \mathrm{mL})$ for identifying the presence of luteal activity was chosen based on a preliminary study (von Leesen et al., 2013).

The function "rle" was used to calculate a step function based on run length encoding. The step function was applied to compute the anestrus period (progesterone values $<0.8 \mathrm{ng} / \mathrm{mL}$ of skim milk) and the length of luteal phases (values $>0.8 \mathrm{ng} / \mathrm{mL}$ ). The detectable amount of progesterone in skim milk per luteal phase was calculated by summarizing all interpolated values within a luteal phase (values $>0.8 \mathrm{ng} / \mathrm{mL}$ ). This presents the area under the curve (AUC).

\section{Reproductive Management, Data on Insemination, and Pregnancy Diagnoses}

Primiparous cows had a voluntary waiting period of about 100 d. All insemination data were recorded, and there was no defined breeding season for the test

Table 5. Overview of group assignment according to the number of negative energy balance breeding values (BV) from DIM 11 to 180 ( $\mathrm{n}=234$ primiparous cows)

\begin{tabular}{lccc}
\hline Number of negative BV across the entire period (DIM 11 to 180) & Class limit & Frequency, \% (no.) \\
\hline Small & Less than mean number + 1/2SD & $\mathrm{i} \leq 91.2$ & $43.16(101)$ \\
Moderate & Mean number $\pm 1 / 2 \mathrm{SD}$ & $91.2<\mathrm{i}<143$ & $26.07(61)$ \\
Large & Greater than mean number $-1 / 2 \mathrm{SD}$ & $\mathrm{i} \geq 143$ & $30.77(72)$ \\
\hline
\end{tabular}

${ }^{1}$ Where class limit $\mathrm{i}$ is the number of negative BV across the entire period (DIM 11 to 180). 


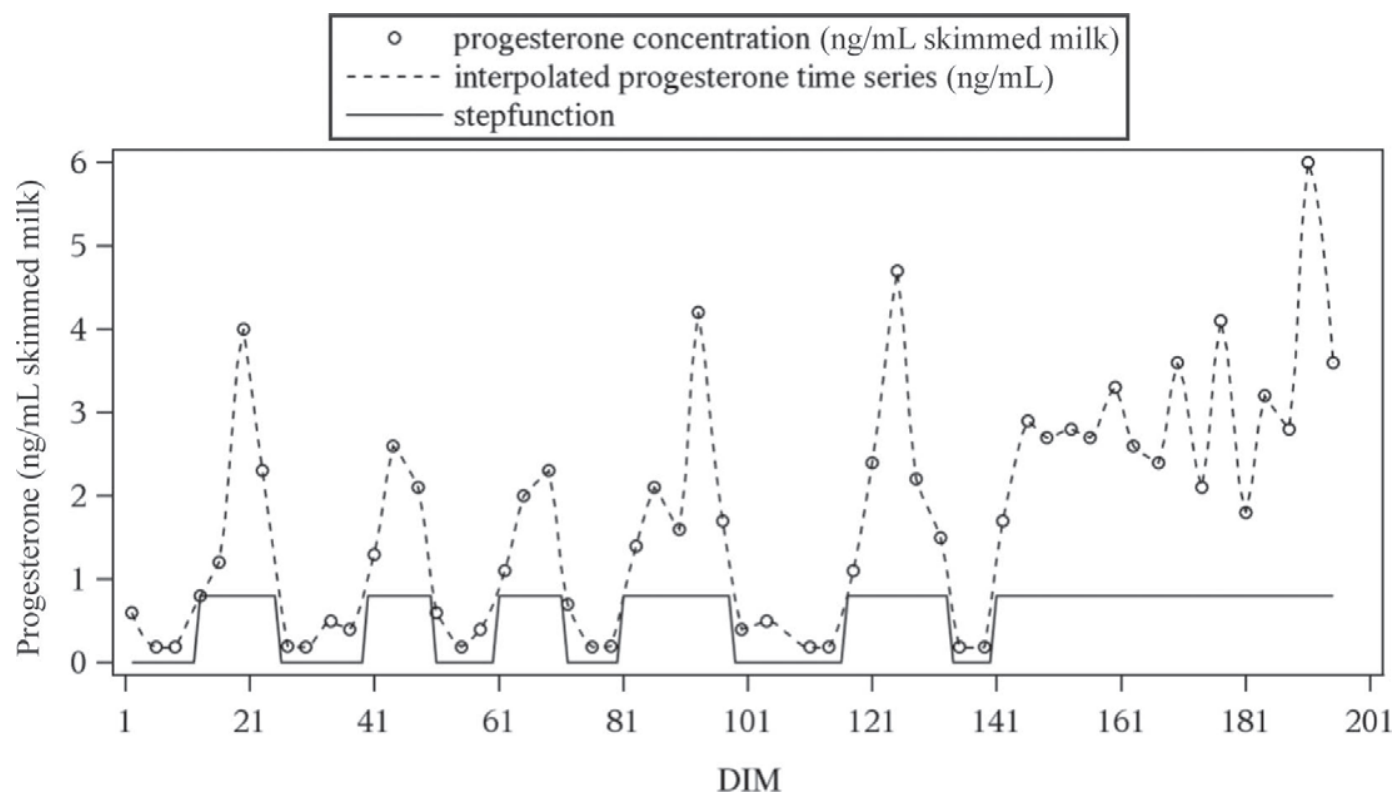

Figure 1. Typically interpolated progesterone profile with step function.

population. Visual detection of estrus supported by activity meter specification (GEA Farm Technologies, Kenilworth, UK) was used to determine time of AI. Experienced AI technicians performed the AI. The herd manager had no insight into the progesterone measurements and veterinarians verified ultrasonographic pregnancy diagnoses $35 \mathrm{~d}$ after insemination or later. For the subset of cows $(\mathrm{n}=255)$ that did not receive hormonal treatments for superovulation, data on insemination and pregnancy diagnoses were used for further investigations.

\section{Effect of Genetic Merit for EB on First Luteal Activity and Subsequent Reproductive Performance}

The effects of genetic merit for energy status on the first luteal activity and subsequent reproductive performance, respectively, were tested using PROC GLM of SAS (SAS Institute, 2004). When subgroups within parameters differed $(P<0.05)$, post hoc tests by Scheffé (PROC GLM) were used to compare the different groups.

\section{RESULTS}

Figure 2 shows the trend of the mean EB (MJ of $\mathrm{NE}_{\mathrm{L}} / \mathrm{d}$ ) and the range of the trait from 11 to 180 DIM. All cows were in a negative EB until DIM 20. Energy balance stabilized around DIM 55, switching from positive to negative and vice versa until DIM 63. The mean EB increased slightly as lactation proceeded, but some cows suffered from a prolonged energy deficit and did not change into a state of positive EB throughout the entire observation period.

A summary of the EB data for 4 specific DIM is given in Table 6 . The mean EB increased by $43.18 \mathrm{MJ}$ of $\mathrm{NE}_{\mathrm{L}}$ from 11 to $55 \mathrm{DIM}$ (i.e., $0.98 \mathrm{MJ} / \mathrm{d}$ ). At 180 DIM, the mean EB was approximately 8 times higher compared with that at 63 DIM. Table 7 summarizes the estimated EBBV on 11, 55, and 180 DIM.

Table 8 illustrates the traits for the resumption of ovarian activity postpartum, which included the time of resumption, the duration of first luteal activity, and the AUC of first luteal activity. All traits were skewed to the right and had high standard deviations.

Table 6. Descriptive statistics for energy balance (MJ of $\mathrm{NE}_{\mathrm{L}} / \mathrm{d}$ ) at DIM 11, 55, 63 and 180 ( $\mathrm{n}=824$ primiparous cows)

\begin{tabular}{llrrrc}
\hline DIM & No. & \multicolumn{1}{c}{ Mean } & Minimum & Maximum & SD \\
\hline 11 & 820 & -42.67 & -133.83 & 39.54 & 34.58 \\
55 & 802 & 0.51 & -80.22 & 102.90 & 34.20 \\
63 & 799 & 2.29 & -91.83 & 137.90 & 36.98 \\
180 & 686 & 18.83 & -86.91 & 120.76 & 33.61 \\
\hline
\end{tabular}


Table 7. Descriptive statistics for the estimated energy balance breeding values at DIM 11,55 , and 180 ( $\mathrm{n}=824$ primiparous cows)

\begin{tabular}{lrrcc}
\hline DIM & Mean & Minimum & Maximum & SD \\
\hline 11 & 1.06 & -64.14 & 81.26 & 19.51 \\
55 & -0.10 & -67.10 & 44.09 & 14.46 \\
180 & 1.44 & -101.11 & 84.02 & 16.03 \\
\hline
\end{tabular}

Table 9 shows the effect of the difference between EBBV for DIM 11 to 55 and the average BV from DIM 11 to 55, respectively, on resumption of ovarian activity. The change in genetic merit from DIM 11 to 55 had a significant effect on the duration of first luteal activity $(P=0.02)$ and on AUC $(P=0.01)$, whereas no significant effect on time of resumption was observed $(P=0.07)$. The average genetic merit for EB in early lactation had only a significant effect on time of resumption of first ovarian activity $(P=0.03)$.

The effect of the genetic disposition for the magnitude and duration of the negative EB on fertility traits is presented in Table 10. Both traits considering only negative BV for DIM 11 to 180 had a significant effect on time of resumption of first ovarian activity.

Table 11 provides an overview of the effect of genetic merit for $\mathrm{EB}$ on the subsequent reproductive performance. For the analyses performed using the 2 parameters "differences between EBBV for DIM 11 and 55" and "average EBBV for DIM 11 to 55," 255 cows with insemination data were available. Only 129 cows became pregnant during the observation period. The first 2 parameters did not have a significant effect on interval from calving to first AI or on days open.
For the analyses performed using the other 2 parameters, which described the genetic disposition for magnitude and duration of negative EB, AI records from 177 cows were available. Of these, 94 cows became pregnant during the study. The genetic disposition for the duration of the energy deficit postpartum had a significant effect on days open. Furthermore, the genetic disposition for the magnitude of the negative EB was significantly associated with interval to first AI $(P=$ $0.02)$, but the post hoc Scheffé test showed no significant differences between the groups.

\section{DISCUSSION}

In early lactation, a mismatch exists between DMI and energy required for milk yield and maintenance (i.e., there is a negative EB). Compensation through increased mobilization of body fat and skeletal muscle is necessary (Butler and Smith, 1989; Bell, 1995). Energy status is driven mainly by individual DMI (Villa-Godoy et al., 1988; Banos and Coffey, 2010). Banos and Coffey (2010) stated that cows in the first week postpartum produced about $92 \%$ of their maximum milk yield, but their feed intake amounted to only $80 \%$ of their highest DM consumption. de Vries and Veerkamp (2000) reported that EB was negative during the first 41.5 DIM, on average. Moreover, Bauman and Currie (1980) found that the average EB was negative within the first 100 DIM. Beever et al. (1998) determined that EB was negative throughout the first $20 \mathrm{wk}$ postpartum. In this study, average EB was negative until 55 DIM. Buttchereit (2011a) reported that primiparous Karkendamm



Figure 2. Means and range (error bars) of energy balance from DIM 11 to $180(\mathrm{n}=824$ primiparous cows). 
Table 8. Traits for the resumption of ovarian activity postpartum ( $\mathrm{n}=334$ primiparous cows)

\begin{tabular}{lccccc}
\hline Trait & No. & Mean & SD & Minimum & Maximum \\
\hline Time of resumption of ovarian activity (d) & 334 & 34.14 & 23.26 & 3.0 & 146.0 \\
Duration of first luteal activity (d) & 334 & 20.05 & 13.91 & 7.0 & 123.0 \\
Area under curve of first luteal activity & 334 & 47.04 & 43.62 & 7.0 & 377.0 \\
\hline
\end{tabular}

cows exhibited a negative EB during the first 42 DIM, on average. Thus, the duration of the energy deficit postpartum has increased for the Karkendamm herd since that time. In addition, a decline in average daily EB from 8.00 MJ of $\mathrm{NE}_{\mathrm{L}}$ (Buttchereit et al., 2011b; including data from March 2006 to October 2010) to $5.16 \mathrm{MJ}$ of $\mathrm{NE}_{\mathrm{L}}$ could be observed for the primiparous Karkendamm cows, which is notable because of the short time elapsing between these studies. Figure 2 illustrates that some cows (42.1\%) did not revert to balanced energy status during the first 180 DIM. Likewise, Villa-Godoy et al. (1988) announced that, by the end of the study (DIM >100 or new pregnancy, respectively), $69 \%$ of the cows could not recuperate their body energy content from the beginning of lactation. In contrast to these results, de Vries and Veerkamp (2000) reported that only $17.5 \%$ of the cows did not reach balanced energy status during the first 180 DIM.

The main objective of this study was to gain a better understanding of how genetic merit for EB influences fertility. Random regression models were applied to derive cow-specific information for every day (daily EBBV) from 11 to 180 DIM. Thereafter, the relationship between fertility and the genetic merit for $\mathrm{EB}$ across lactation was studied. The lactation curves for daily EBBV were described by 4 parameters with 3 subgroups each. The first parameter (differences between BV for DIM 11 and 55) indicated whether or not the genetic merit was subject to change in early lactation and, if so, also described the direction or amount of change. The second parameter (average BV from DIM 11 to 55) referred to the average genetic merit for EB within the period in which cows were in a negative EB, on average. Two further parameters (sum and number of negative EBBV from DIM 11 to 180) referred to the whole observation period and were used to describe the genetic disposition for the magnitude and duration of the energy deficit. On a phenotypic level, similar traits were studied by Villa-Godoy et al. (1988) and Reist et al. (2003).

Three parameters were extracted from progesterone profiles and used to assess the effect of differing genetic merit for $\mathrm{EB}$ on fertility. These parameters described the time of resumption of first ovarian activity, the duration and the AUC of first luteal activity. On average, the first luteal activity was at DIM 34.14 $( \pm 23.26 \mathrm{~d})$. The current results are in agreement with Petersson et al. (2006). Those authors observed CLA on DIM $33.5( \pm 22.3 \mathrm{~d})$ for Swedish Red breed and on DIM $34.5( \pm 23.7 \mathrm{~d})$ for Swedish White breed. Opsomer et al. (1998) found slightly longer CLA for Belgian dairy cattle $(37 \pm 27$ DIM), whereas Holstein-Friesian dairy cows in Northern Ireland showed CLA on DIM 30.1 ( $\pm 0.46 \mathrm{~d}$; McCoy et al., 2006). The duration of first luteal activity (mean $=20.05 \mathrm{~d}$ ) was in line with physiological expectations (Lamming and Darwash, 1998). However, it should be noted that there were also atypical progesterone profiles such as shortened and prolonged luteal phases. These results are in agreement with Lamming and Darwash (1998), Opsomer et al. (1998), Royal et al. (2000), Shrestha et al. (2004), Hommeida et al. (2011), and Ranasinghe et al. (2011).

All 4 parameters describing the genetic merit for EB had a distinct effect on time of resumption of first

Table 9. Effect of the difference between energy balance breeding values (BV) for DIM 11 and 55 and the average BV from DIM 11 to 55 , respectively, on the resumption of ovarian activity postpartum ( $\mathrm{n}=334$ primiparous cows $)$

\begin{tabular}{|c|c|c|c|c|c|c|c|c|c|}
\hline \multirow[b]{2}{*}{ Trait } & \multicolumn{3}{|c|}{ Time of resumption } & \multicolumn{3}{|c|}{$\begin{array}{l}\text { Duration of first } \\
\text { luteal activity }\end{array}$} & \multicolumn{3}{|c|}{$\begin{array}{l}\text { Area under the curve } \\
\text { of first luteal activity }\end{array}$} \\
\hline & No. & Mean & $\mathrm{SD}$ & No. & Mean & $\mathrm{SD}$ & No. & Mean & $\mathrm{SD}$ \\
\hline \multicolumn{10}{|c|}{ Difference between BV for DIM 11 and 55} \\
\hline Positive & 97 & $30.15^{\mathrm{a}}$ & 17.69 & 97 & $23.09^{\mathrm{a}}$ & 16.72 & 97 & $57.59^{\mathrm{a}}$ & 58.36 \\
\hline Low to moderate & 187 & $34.88^{\mathrm{a}}$ & 25.50 & 187 & $18.38^{\mathrm{b}}$ & 12.92 & 187 & $41.33^{\mathrm{b}}$ & 35.62 \\
\hline Negative & 50 & $39.10^{\mathrm{a}}$ & 23.39 & 50 & $20.42^{\mathrm{ab}}$ & 10.41 & 50 & $47.94^{\mathrm{ab}}$ & 33.63 \\
\hline \multicolumn{10}{|c|}{ Average BV for DIM 11 to 55} \\
\hline Low & 80 & $39.64^{\mathrm{b}}$ & 28.65 & 80 & $20.53^{\mathrm{a}}$ & 14.05 & 80 & $49.96^{\mathrm{a}}$ & 50.09 \\
\hline
\end{tabular}

\footnotetext{
${ }^{a, b}$ Means with different superscripts within a column and trait are significantly different $(P<0.05)$.
} 
Table 10. Effect of genetic disposition for magnitude and duration of negative energy balance on the resumption of ovarian activity postpartum ( $\mathrm{n}=234$ primiparous cows)

\begin{tabular}{|c|c|c|c|c|c|c|c|c|c|}
\hline \multirow[b]{2}{*}{ Trait } & \multicolumn{3}{|c|}{ Time of resumption } & \multicolumn{3}{|c|}{$\begin{array}{l}\text { Duration of first } \\
\text { luteal activity }\end{array}$} & \multicolumn{3}{|c|}{$\begin{array}{l}\text { Area under the curve } \\
\text { of first luteal activity }\end{array}$} \\
\hline & No. & Mean & SD & No. & Mean & SD & No. & Mean & $\mathrm{SD}$ \\
\hline Low negative & 102 & $30.96^{\mathrm{a}}$ & 18.55 & 102 & $21.08^{\mathrm{a}}$ & 9.15 & 102 & $49.11^{\mathrm{a}}$ & 45.85 \\
\hline Moderate negative & 78 & $33.26^{\mathrm{ab}}$ & 21.85 & 78 & $18.06^{\mathrm{a}}$ & 17.03 & 78 & $41.26^{\mathrm{a}}$ & 26.27 \\
\hline High negative & 54 & $43.33^{\mathrm{b}}$ & 33.01 & 54 & $20.44^{\mathrm{a}}$ & 14.49 & 54 & $51.17^{\mathrm{a}}$ & 55.49 \\
\hline Moderate & 69 & $27.07^{\mathrm{d}}$ & 15.47 & 69 & $22.07^{\mathrm{a}}$ & 18.19 & 61 & $50.84^{\mathrm{a}}$ & 45.22 \\
\hline Large & 72 & $34.43^{\mathrm{cd}}$ & 20.15 & 72 & $19.97^{\mathrm{a}}$ & 14.04 & 72 & $47.03^{\mathrm{a}}$ & 42.47 \\
\hline
\end{tabular}

${ }_{\mathrm{a}, \mathrm{b}}$ Means with different superscripts within a column and trait are significantly different $(P<0.01)$.

${ }^{\mathrm{c}, \mathrm{d}}$ Means with different superscripts within a column and trait are significantly different $(P<0.05)$.

${ }^{1} \mathrm{BV}=$ energy balance breeding values.

ovarian activity. We found that the subgroups "high average BV for DIM 11 to 55" and "low negative sum of negative BV across the entire period" with the highest genetic merit for EB were superior to the other subgroups. These cows exhibited their first luteal activity significantly earlier (9 and $13 \mathrm{~d}$, respectively) than cows that had the lowest genetic merit for EB. Cows in the subgroups "positive difference (downward sloping BV curve)" also showed their first luteal activity about $9 \mathrm{~d}$ earlier compared with cows in the subgroup "negative difference (rising BV curve)," although the difference was not statistically significant. In contrast to the other results, cows with a small number of negative EBBV were significantly inferior in terms of reproductive performance. On the other hand, the subgroup with a moderate number of negative EBBV was superior to the subgroup of cows genetically inclined to suffer from a prolonged negative $\mathrm{EB}$, but this difference was not significant.

Villa-Godoy et al. (1988), Spicer et al. (1990), and Reist et al. (2003) did not find phenotypic relationships between anovulatory periods postpartum and average EB. However, Staples et al. (1990) reported that cows showing their first luteal activity after DIM 63 had a lower feed intake and greater loss of BW and, therefore, a higher magnitude of negative EB. This is consistent with Patton et al. (2007), who indicated that the average daily EB within the first 4 wk postpartum is positively related to the likelihood of fewer days to resumption of ovarian activity. Banos and Coffey

Table 11. Effect of parameters describing the genetic merit for energy balance on the subsequent reproductive performance

\begin{tabular}{|c|c|c|c|c|c|c|}
\hline Trait & \multicolumn{3}{|c|}{ Interval from calving to first AI } & \multicolumn{3}{|c|}{ Days open } \\
\hline \multicolumn{7}{|c|}{ Difference between $\mathrm{BV}^{1}$ for DIM 11 and 55} \\
\hline Low to moderate & 140 & $137.64^{\mathrm{a}}$ & 58.52 & 66 & $143.55^{\mathrm{a}}$ & 53.21 \\
\hline Negative & 41 & $146.56^{\mathrm{a}}$ & 82.76 & 19 & $153.58^{\mathrm{a}}$ & 83.82 \\
\hline \multicolumn{7}{|c|}{ Average $\mathrm{BV}^{1}$ for DIM 11 to 55} \\
\hline \multicolumn{7}{|c|}{$\begin{array}{l}\text { Sum of negative } \text { BV }^{1} \text { across the } \\
\text { entire period (DIM } 11 \text { to } 180 \text { ) }\end{array}$} \\
\hline Low negative & 77 & $151.82^{\mathrm{a}}$ & 73.14 & 43 & $169.84^{\mathrm{a}}$ & 96.60 \\
\hline Moderate negative & 60 & $125.12^{\mathrm{a}}$ & 46.07 & 32 & $141.75^{\mathrm{a}}$ & 39.85 \\
\hline High negative & 40 & $157.85^{\mathrm{a}}$ & 76.94 & 19 & $149.26^{\mathrm{a}}$ & 55.65 \\
\hline \multicolumn{7}{|c|}{$\begin{array}{l}\text { Number of negative } \text { BV }^{1} \text { across the } \\
\text { entire period (DIM } 11 \text { to } 180 \text { ) }\end{array}$} \\
\hline
\end{tabular}

$\overline{\mathrm{a}, \mathrm{b}}$ Means with different superscripts within a column and trait are significantly different $(P<0.05)$.

${ }^{1} \mathrm{BV}=$ energy balance breeding value. 
(2010) investigated the genetic association between fertility and direct and indirect body energy traits recorded across lactation. They reported that the interval from calving to resumption of ovarian activity showed a negative genetic correlation $\left(\mathrm{r}_{\mathrm{g}}\right)$ with BCS $\left(\mathrm{r}_{\mathrm{g}}=-0.50\right.$ to -0.74 ), in particular within the first 25 to 50 DIM. Days of negative EB, rate of recovery of $\mathrm{EB}$ during the postpartum period of negative EB, sum of negative EB, nadir of energy content, as well as days from calving to nadir of energy content were negatively but not significantly correlated with the onset of first ovarian activity. Veerkamp et al. (2000) also reported a negative genetic correlation $\left(r_{g}=-0.60\right)$ between resumption of ovarian activity and EB, but this correlation was associated with a high standard error as well.

Regarding the parameters "duration of first luteal phase" and "area under curve of first luteal activity," the subgroup with a "positive difference between BV from DIM 11 to 55" had a significantly longer luteal phase and a greater AUC, respectively, than cows with a low to moderate or negative difference. This result is in contrast to our aforementioned results; therefore, it remains unclear whether the shape of EBBV curve is an adequate selection criterion.

Considering the parameter AUC, Spicer et al. (1990) reported similar results. Cows with negative EB during the first $12 \mathrm{wk}$ postpartum had a smaller progesterone area during first and second estrous cycle compared with cows that had a positive EB during the first 12 wk postpartum $(P<0.01)$. This is not, however, in line with Villa-Godoy et al. (1988), who did not find a phenotypic association between AUC and EB; that is, regarding the detectable amount of progesterone in skim milk (area) of the first estrous cycle and the mean EB (DIM 1 to 9). Nevertheless, they found a relation for the second and third estrous cycle. Those authors also reported that the time from parturition to EB nadir and the magnitude of EB nadir were associated with progesterone in skim milk (AUC) within second and third estrous cycle. Other studies indicated that the detectable amount of progesterone in milk is important for embryo survival after AI (Stronge et al., 2005; McNeill et al., 2006). Thus, further investigations are needed to assess the effect of genetic merit for EB on reduced embryo survival due to decreased progesterone concentrations.

A subset of cows did not receive hormonal applications for superovulation. For these cows, insemination data were available, and the influence of genetic merit for $\mathrm{EB}$ on the interval to first AI was assessed. Cows genetically inclined to a prolonged or severe negative EB had a longer interval from calving to first AI, but although the global $F$-test showed a significant effect of both traits on fertility, differences between single groups were not statistically significant $(P>0.05)$. This could be due to the small sample size, but it is more likely due to the bull dam performance test that was run at the Karkendamm farm within the observation period. Cows that passed the performance test were not inseminated until DIM 100. Thus, the effect of the genetic merit for $\mathrm{EB}$ on the interval to first $\mathrm{AI}$ might be reduced and should be re-evaluated on an independent data set. However, Berry et al. (2003) investigated the genetic relationships between BCS and fertility and found a negative genetic correlation between mean BCS and days to first service of -0.37 . This is also in accordance with de Haas et al. (2007) who estimated a genetic correlation between BCS and days to first service ranging from -0.14 to -0.45 across lactation.

Regarding days open, parameters describing the genetic merit for EB showed no distinct effects. We had expected that cows with a high and medium genetic merit for EB would be superior in days open (lower number) compared with cows with a low genetic merit for EB. However, all we found were significant longer days open for cows with the lowest genetic merit expressed through many days with negative EBBV compared with cows that had moderate numbers of days with negative EBBV. The small number of animals (n =94) might explain these results. However, this result is comparable with the findings of Reist et al. (2003) to a certain extent. They reported that cows with a lower severity of EB nadir were more likely to have fewer days open.

\section{CONCLUSIONS}

Cows with a higher genetic merit for early lactation EB had significantly fewer days to first luteal activity. Thus, selection on above average EBBV from 11 to 55 DIM would reduce the calving interval and therefore has the potential to enhance productivity. Likewise, a comparatively small number of days with negative EBBV from 11 to 180 DIM is favorable. Furthermore, evidence indicates that the genetic merit for EB determines the amount of detectable progesterone in skim milk but this should be re-evaluated on a more comprehensive data set. Moreover, further investigations are needed to assess the effect of genetic merit for EB on reduced embryo survival by decreased progesterone concentrations. It must be taken into account that (up-to-date) EBBV can only be estimated for research herds, because recording of individual cow feed intake is not feasible under commercial conditions. Nevertheless, international networking; for example, within in the framework of the project gDMI (global Dry Matter Initiative), and the use of genomic tools might allow identification of positive QTL variance in specifically 
designed data sets and to use this knowledge in advanced breeding programs.

\section{ACKNOWLEDGMENTS}

We gratefully acknowledge the financial support of the Federal Office for Agriculture and Food and the Federal Ministry of Food, Agriculture and Consumer Protection for the project "Innovative methods of trait recording in dairy cattle as a basis of the modern breeding program of the Nord-Ost-Genetic." Furthermore, gratitude is expressed to our cooperation partners our cooperation partners Nord-Ost Genetic GmbH \& Co. KG (Verden, Germany), Martin-Luther-University Halle-Wittenberg (Halle, Germany), Landesforschungsanstalt für Landwirtschaft und Fischerei Mecklenburg-Vorpommern (Gülzow, Germany), Sächsisches Staatsministerium für Umwelt und Landwirtschaft (Dresden, Germany), and the Leibniz Institute for Farm Animal Biology (Dummerstorf, Germany). The authors also acknowledge the expert technical assistance of $\mathrm{H}$. Kluding and E. Lass (Institute of Animal Breeding and Husbandry, Christian-Albrechts-University, Kiel, Germany).

\section{REFERENCES}

Ali, T. E., and L. R. Schaeffer. 1987. Accounting for covariances among test day milk yields in dairy cows. Can. J. Anim. Sci. 67:637-644.

Banos, G., and M. P. Coffey. 2010. Genetic association between body energy measured throughout lactation and fertility in dairy cattle. Animal 4:189-199.

Banos, G., M. P. Coffey, E. Wall, and S. Brotherstone. 2006. Genetic relationship between first-lactation body energy and later-life udder health in dairy cattle. J. Dairy Sci. 89:2222-2232.

Bauman, D. E., and B. W. Currie. 1980. Partitioning of nutrients during pregnancy and lactation: A review of mechanisms involving homeostasis and homeorhesis. J. Dairy Sci. 63:1514-1529.

Beever, D. E., S. B. Cammell, J. D. Sutton, N. Rowe, and G. E. Perrott. 1998. Energy metabolism in high yielding cows. Proc. Br. Soc. Anim. Sci. Annu. Conf., Scarborough, UK. Br. Soc. Anim. Sci., Penicuik, UK.

Bell, A. W. 1995. Regulation of organic nutrient metabolism during transition from late pregnancy to early lactation. J. Anim. Sci. 73:2804-2819.

Berry, D. P., F. Buckley, P. Dillon, R. D. Evans, M. Rath, and R. F. Veerkamp. 2003. Genetic relationships among body condition score, body weight, milk yield, and fertility in dairy cows. J. Dairy Sci. 86:2193-2204.

Butler, W. R., and R. D. Smith. 1989. Interrelationships between energy balance and postpartum reproductive function in dairy cattle. J. Dairy Sci. 72:767-783.

Buttchereit, N. 2011a. Model evaluation and estimation of genetic parameters for energy balance and related traits in dairy cows. PhD Thesis. Christian-Albrechts-University, Kiel, Germany.

Buttchereit, N., E. Stamer, W. Junge, and G. Thaller. 2010. Evaluation of five lactation curve models fitted for fat:protein ratio of milk and daily energy balance. J. Dairy Sci. 93:1702-1712.

Buttchereit, N., E. Stamer, W. Junge, and G. Thaller. 2011b. Short communication: Genetic relationships among daily energy balance, feed intake, body condition score, and fat to protein ratio of milk in dairy cows. J. Dairy Sci. 94:1586-1591.

Collard, B. L., P. J. Boettcher, J. C. M. Dekkers, D. Petitclerc, and L. R. Schaeffer. 2000. Relationships between energy balance and health traits of dairy cattle in early lactation. J. Dairy Sci. 83:2683-2690

de Haas, Y., L. L. G. Janss, and H. N. Kadarmideen. 2007. Genetic correlations between body condition scores and fertility in dairy cattle using bivariate random regression models. J. Anim. Breed. Genet. 124:277-285.

de Vries, M. J., and R. F. Veerkamp. 2000. Energy balance of dairy cattle in relation to milk production variables and fertility. J. Dairy Sci. 83:62-69.

Gilmour, A. R., B. J. Gogel, B. R. Cullis, and R. Thompson. 2009. ASReml User Guide. Release 3.0.VSN International Ltd., Hemel Hempstead, UK.

Hommeida, A., T. Nakao, and H. Kubota. 2011. Reduced pregnancy rates in lactating dairy cows inseminated following short or prolonged luteal phases. Anim. Vet. Adv. 10:2167-2171.

Hüttmann, H., E. Stamer, W. Junge, G. Thaller, and E. Kalm. 2009 Analysis of feed intake and energy balance of high-yielding first lactating Holstein cows with fixed and random regression models. Animal 3:181-188.

Johannesson. T., H. Bjornsson, and Icelandic Meteorological Office. 2009. Stineman, a consistently well behaved method of interpolation. Accessed Aug. 14, 2012. http://cran.r-project.org/web/ packages/stinepack/stinepack.pdf.

Kirchgeßner, M. 1997. Tierernährung. Vol. 10. DLG-Verlag, Frankfurt am Main, Germany.

Lamming, G. E., and A. O. Darwash. 1998. The use of milk progesterone profiles to characterise components of subfertility in milked dairy cows. Anim. Reprod. Sci. 52:175-190.

Lucy, M. C. 2001. Reproductive loss in high-producing dairy cattle: Where will it end? J. Dairy Sci. 84:1277-1293.

McCoy, M. A., S. D. Lennox, C. S. Mayne, W. J. McCaughey, H. W. J. Edgar, D. C. Catney, M. Verner, D. R. Mackey, and A. W. Gordon. 2006. Milk progesterone profiles and their relationship with fertility, production and disease in dairy cows in Northern Ireland. Anim. Sci. 82:213-222.

McNeill, R. E., M. G. Diskin, J. M. Sreenan, and D. G. Morris. 2006. Associations between milk progesterone concentration on different days and with embryo survival during the early luteal phase in dairy cows. Theriogenology 65:1435-1441.

Opsomer, G., M. Coryn, H. Deluyker, and A. de Kruif. 1998. An analysis of ovarian dysfunction in high yielding dairy cows after calving based on progesterone profiles. Reprod. Domest. Anim. 33:193-204.

Patton, J., D. A. Kenny, S. McNamara, J. F. Mee, F. P. O'Mara, M. G. Diskin, and J. J. Murphy. 2007. Relationships among milk production, energy balance, plasma analytes, and reproduction in Holstein-Friesian cows. J. Dairy Sci. 90:649-658.

Petersson, K.-J., E. Strandberg, H. Gustafsson, and B. Berglund. 2006. Environmental effects on progesterone profile measures of dairy cow fertility. Anim. Reprod. Sci. 91:201-214.

R Development Core Team. 2012. R: A Language and Environment for Statistical Computing. The R Foundation for Statistical Computing, Vienna, Austria.

Ranasinghe, R. M., T. Nakao, K. Yamada, K. Koike, A. Hayashi, and C. M. Dematawewa. 2011. Characteristics of prolonged luteal phase identified by milk progesterone concentrations and its effects on reproductive performance in Holstein cows. J. Dairy Sci. 94:116-127.

Reist, M., D. K. Erdin, D. von Euw, K. M. Tschümperlin, H. Leuenberger, H. M. Hammon, C. Morel, C. Philipona, Y. Zbinden, N. Künzi, and J. W. Blum. 2003. Postpartum reproductive function: Association with energy, metabolic and endocrine status in high yielding dairy cows. Theriogenology 59:1707-1723.

Renner, E. 1970. Messfehler von Bestimmungsmethoden. Mathematisch-statistische Methoden in der praktischen Anwendung. E. Renner, ed. Verlag Paul Parey, Berlin, Germany.

Royal, M., A. O. Darwash, A. P. F. Flint, R. Webb, J. A. Wooliams, and G. E. Lamming. 2000. Declining fertility in dairy cattle: Changes in traditional and endocrine parameters of fertility. Anim. Sci. 70:487-501. 
SAS Institute. 2004. SAS/STAT User's Guide. Version 9.0. SAS Institute Inc., Cary, NC.

Shrestha, H. K., T. Nakao, T. Suzuki, T. Higaki, and M. Akita. 2004. Effects of abnormal ovarian cycles during pre-service period postpartum on subsequent reproductive performance of high-producing Holstein cows. Theriogenology 61:1559-1571.

Spicer, L. J., W. B. Tucker, and G. D. Adams. 1990. Insulin-like growth factor-I in dairy cows: Relationships among energy balance, body condition, ovarian activity, and estrous behavior. J. Dairy Sci. 73:929-937.

Staples, C. R., W. W. Thatcher, and J. H. Clark. 1990. Relationship between ovarian activity and energy status during the early postpartum period of high producing dairy cows. J. Dairy Sci. 73:938-947.

Stronge, A. J. H., J. M. Sreenan, M. G. Diskin, J. F. Mee, D. A. Kenny, and D. G. Morris. 2005. Post-insemination milk progesterone concentration and embryo survival in dairy cows. Theriogenology 64:1212-1224.

Veerkamp, R. F., J. K. Oldenbroek, H. J. van der Gaast, and J. H. van der Werf. 2000. Genetic correlation between days until start of luteal activity and milk yield, energy balance, and live weights. J. Dairy Sci. 83:577-583.

Villa-Godoy, A., T. L. Hughes, R. S. Emery, L. T. Chapin, and R. L. Fogwell. 1988. Association between energy balance and luteal function in lactating dairy cows. J. Dairy Sci. 71:1063-1072.

von Leesen, R., J. Tetens, W. Junge, and G. Thaller. 2013. Mathematical approaches to detect low concentrations in progesterone profiles. Animal 7:2008-2015. 